\title{
INCREASED ACTIVITY AND LEARNING OUTCOMES THROUGH BIOLOGY WITH GUIDED DISCOVERY \\ LEARNING MODEL
}

\section{Sapiudin*}

Departement Post Graduate Educational Technology

State University of Jakarta,

Indonesia

\section{Basuki Wibawa}

Departement Post Graduate Educational Technology

State University of Jakarta,

Indonesia

*Corrosponding author's Email: sapiudin_tp14S3@mahasiswa.unj.ac.id, bwibawa@unj.ac.id

Author's Biography

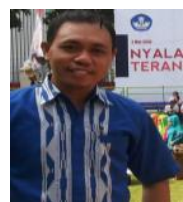

Sapiudin, Place and Date of birth: Tapunggaya, 12 Sepember 1979; Education: Undergraduate of Biology Study Program, Science Faculty of Haluoleo University; Master at Education Technology of State University of Jakarta; Doctoral Program at Education Technology of State University of Jakarta; Job Experiences: Teacher at Senior High School 1 Asera, North Konawe Regency, Southeast Sulawesi, Indonesia; Teacher at Junior High School 4 Kendari, Southeast Sulawesi, Indonesia; Teacher at Surya Institute of Papua Students in Jakarta, Indonesia; Consultant at Education and Culture Ministry, Indonesia; Redaction Team at Jurnal Education Technology Program in State University of Jakarta.

Peer-review under responsibility of $3^{\text {rd }}$ Asia International Multidisciplanry Conference 2019 editorial board (http://www.utm.my/asia/our-team/) () 2019 Published by Readers Insight Publisher, lat 306 Savoy Residencia, Block 3 F11/1,44000 Islamabad. Pakistan, info@readersinsight.net This is an open access article under the CC BY-NC-ND license (http://creativecommons.org/licenses/by-nc-nd/4.0/). 


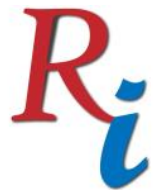

\section{Asia Proceedings of Social Sciences}

(APSS)

www.readersinsight.net/APSS

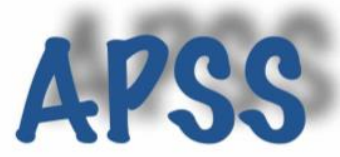

\section{Rese a r ch H i g h I igh t s}

The purpose of this study is to improve the activities and student learning outcomes on biology subjects through the application of guided discovery learning models. This research is a type of Classroom Action Research. Classroom Action Research is carried out in 2 cycles. The results showed that the application of guided discovery learning models can improve the activity and learning outcomes of students of class XI IPA 1 SMAN 1 Asera. Learning outcomes in the cognitive realm increased by $22.77 \%$ after the action of the first cycle and amounted to $11.50 \%$ after the second cycle of action and psychomotor domain learning outcomes experienced an increase of $15.50 \%$ from the first cycle of action to the second cycle. The application of a guided learning model can improve student learning activities. Student learning activities increased by $40.25 \%$ after action I and by $9.88 \%$ after cycle II.

Keyword: Activities and Learning Outcomes, Guided Discovery Model

\section{Research Objectives}

Biology subjects in high school are developed through the ability to think analytically, inductively, and deductively to solve problems related to natural problems. Qualitative and quantitative problem solving is done by using understanding in the fields of mathematics, physics, chemistry and other supporting knowledge. Achievement of learning goals must be approved to the maximum to support the success of learning in the classroom or in the outside class. The success of the learning process in class participation by various factors. One of them is a learning model that matches the learning objectives to be achieved. The teacher is a subject who is very interested in teaching and educating students, while students are subject to education. The main problem in biology learning is how to connect facts that have been seen and experienced by students in everyday life with biological concepts, so as to produce knowledge that understands in the minds of students. During this time, understand students more about elaborating the concept of biology, without understanding what and how the meaning contained in the concept. so that the use of guided discovery learning models becomes a solution to increase the activity and learning outcomes of Biology.

\section{Methodology}

This research includes Class Action Research conducted in order to improve student activity and learning outcomes of students of class XI IPA 1 Asera 1 High School (Stringer, 2014). The research used was descriptive-qualitative, carried out in two cycles, each cycle consisting of four stages, namely action planning, action implementation, action observation, and reflection. Classroom Action Research was conducted in 8 meetings, namely 4 meetings in the first cycle and 4 meetings in the second cycle. At each meeting carried out using a guided discovery learning model. The subjects of this study were students of class XI IPA 1 of SMAN Asera which consisted of 32 students, with respiration system material and excretion system. The steps in the study consist of pre-research and planning, action, observation, reflection. After reflection will be continued by planning again which is the basis for solving further problems. Research data is collected through student test results at the end of each cycle for cognitive learning outcomes and collection of rubrics during learning for student learning activities, student learning outcomes in the psychomotor domain (Slavin, 2011). 


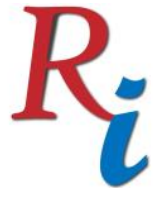

\section{Asia Proceedings of Social Sciences}

(APSS)

www.readersinsight.net/APSS

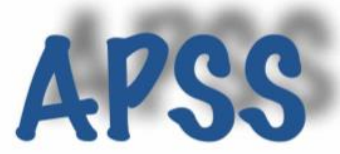

\section{Results}

The use of guided discovery learning models can improve student learning activities. Learning outcomes in the cognitive domain increased by $22.77 \%$ after the first cycle of action and amounted to $11.50 \%$ after the second cycle. And psychomotor domain learning outcomes have increased by $15.50 \%$ from cycle I to cycle II. The application of a guided learning model can improve student learning activities. Student learning activities increased by $40.25 \%$ after action I and by $9.88 \%$ after cycle II. Increased student learning activities occur after applied guided discovery learning. guided inquiry learning process in student learning activities, namely introductory phase, open phase, convergent phase and closing phase and application. The advantages of a guided discovery model when students are very active learning to find something new and the teacher always provides guidance to students who increase difficulties. Eggen and Kauchak (2012) states that the ability to promote student motivation is one of the major strengths of guided discovery. Alex and Olubusuyi (2013) States that the study has shown the potency of guided discovery learning strategy in improving student's performance. Equally, findings from the present study have also shown that gender has no role to play in the performance of the students.

\section{Findings}

The use of guided discovery learning models encourages students to be able to conduct investigations and appreciate the role of critical experiences in the learning process, encourage the development of natural curiosity in students and provide opportunities for students to build new knowledge and understanding based on real experience, so that the learning process can increase the activity and learning outcomes of students in class XI IPA 1 Asera 1 High School.

\section{Acknowledgement}

We would like to thank you for the Doctoral Dissertation Research Grant to the Ministry of Finance of the Republic of Indonesia Education Fund Management Institute (LPDP) in 2016.

\section{References}

Alex, M. Akanmu, and Olubusuyi, M. Fajemidagba (2013) Guided-discovery Learning Strategy and Senior School Students Performance in Mathematics in Ejigbo, Nigeria, Journal of Education and Practice, Vol.4, No.12, 2013.

Eggen, Paul dan Don Kauchak, (2012), Strategic and Model For Teacher: Teaching and Content and Thinking Skills, Sixth Edition, Pearson Edition, Inc. Boston.

Hosnan, M., (2014). Pendekatan Saintifik dan Kontekstual dalam Pembelajaran Abad 21, Kunci Sukses Implementasi Kurikulum 2013. Bogor. Ghalia Indonesia.

Slavin, E., Robert, (2011) Educational Psychology, Theory and Practice $9^{\text {th }}$ Edition. Terjemahan Samosir M., PT. Indeks : Jakarta.

Stringer, T. Ernest (2014) Action Research 4 Edition, Sage: United States of America. 